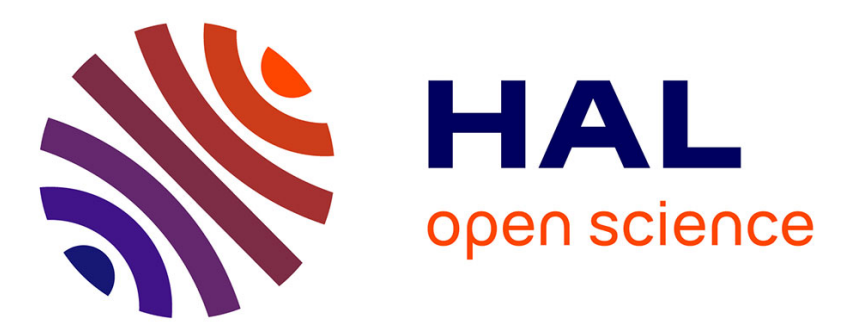

\title{
Calcium phosphate based materials starting from calcium carbonate and orthophosphoric acid for the removal of lead(II) from an aqueous solution
} Doan Pham Minh, Ngoc Dung Tran, Ange Nzihou, Patrick Sharrock

\section{- To cite this version:}

Doan Pham Minh, Ngoc Dung Tran, Ange Nzihou, Patrick Sharrock. Calcium phosphate based materials starting from calcium carbonate and orthophosphoric acid for the removal of lead(II) from an aqueous solution. Chemical Engineering Journal, 2014, 243, p. 280-288. 10.1016/j.cej.2014.01.032 . hal-01611607

\author{
HAL Id: hal-01611607 \\ https://hal.science/hal-01611607
}

Submitted on 20 Oct 2018

HAL is a multi-disciplinary open access archive for the deposit and dissemination of scientific research documents, whether they are published or not. The documents may come from teaching and research institutions in France or abroad, or from public or private research centers.
L'archive ouverte pluridisciplinaire HAL, est destinée au dépôt et à la diffusion de documents scientifiques de niveau recherche, publiés ou non, émanant des établissements d'enseignement et de recherche français ou étrangers, des laboratoires publics ou privés. 


\title{
Calcium phosphate based materials starting from calcium carbonate and orthophosphoric acid for the removal of lead(II) from an aqueous solution
}

\author{
Doan Pham Minh*, Ngoc Dung Tran, Ange Nzihou, Patrick Sharrock \\ Université de Toulouse, Mines Albi, UMR CNRS 5302, Centre RAPSODEE, Campus Jarlard, F-81013 Albi cedex 09, France
}

G R A P H I C A L A B S T R A C T

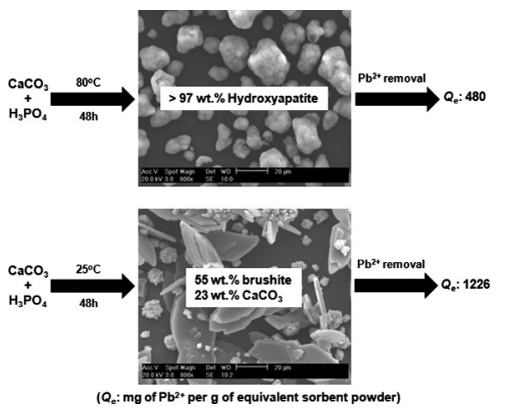

A B S T R A C T

Calcium phosphates starting from calcium carbonate and orthophosphoric acid as unconventional and low cost initial reactants were investigated in the removal from aqueous solution of lead(II) as model heavy metal. Sorbent in gel form, which was directly obtained from the reaction of calcium carbonate powder and orthophosphoric acid, and sorbent in powder form, which was obtained by filtration and drying of the gel at room temperature showed the highest reactivity for the removal of lead(II). The sorption capacity could reach up to $1226 \mathrm{mg}$ of lead(II) per gram of powder sorbent. On the other hand, the conventional drying overnight at $105{ }^{\circ} \mathrm{C}$ decreased the reactivity of the sorbent in powder form. The intermediates of the reaction between calcium carbonate and orthophosphoric acid, including brushite $\left(\mathrm{CaHPO}_{4} \cdot 2 \mathrm{H}_{2} \mathrm{O}\right)$, monetite $\left(\mathrm{CaHPO}_{4}\right)$ and MCPM $\left(\mathrm{Ca}\left(\mathrm{H}_{2} \mathrm{PO}_{4}\right)_{2} \cdot \mathrm{H}_{2} \mathrm{O}\right)$ were found to be more active than hydroxyapatite $\left(\mathrm{Ca}_{10}\left(\mathrm{PO}_{4}\right)_{6}(\mathrm{OH})_{2}\right)$ which was the final stable product of the reaction between calcium carbonate and orthophosphoric acid. Lead hydroxyapatite $\left(\mathrm{Pb}_{10}\left(\mathrm{PO}_{4}\right)_{6}(\mathrm{OH})_{2}\right)$ was the main crystalline phase formed from the contact of calcium phosphate based sorbents with lead(II) nitrate solution. It was only formed at the external surface or surface of open-pores of calcium phosphate particles, highlighted by SEM characterization. The results obtained open new prospects for the design of efficient orthophosphate-based sorbents for the removal of lead(II) and other heavy metals from liquid effluents.

\section{Introduction}

Lead $(\mathrm{Pb})$, a typical heavy metal, is indeed toxic and environmental contamination with $\mathrm{Pb}$ causes serious injury to both the plant and animal kingdoms. Lead can interfere with the metabo-

\footnotetext{
* Corresponding author. Tel.: +33 563493258; fax: +33 563493043

E-mail address: doan.phamminh@mines-albi.fr (D. Pham Minh).
}

lism of other essential metals such as copper and zinc, and can indirectly cause other problems such as oxidative stress, inhibition of DNA repair, and cognitive deficits in children [1,2]. Despite its toxicity which limits its use, lead is widely used for different applications, in particular as electrodes in the lead-acid batteries [3,4], photovoltaic cells [5], lead glasses [6], lead paint [7], etc. In parallel with its large use, lead leaches into the environment by erosion of contaminated soil sites, or from air as a consequence of lead-con- 
taining waste incineration. In order to eliminate or reduce environmental lead mobility, highly effective and low-cost processes for lead abatement are continuously sought after.

In liquid phase, the most common method for the treatment of heavy metals consists in separation processes, wherein soluble metal ions are transformed into insoluble forms (simple hydroxide precipitates when possible) or are fixed on a solid substrate (sorbent) and therefore are separated from the liquid phase. During the last decades, calcium phosphates, and particularly calcium hydroxyapatite $\left(\mathrm{Ca}_{10}\left(\mathrm{PO}_{4}\right)_{6}(\mathrm{OH})_{2}\right.$, Ca-HA), attracted much interest because of their high potential application for the remediation of toxic metals in liquid wastes [8-12]. For example, in the removal of lead, the sorption capacity $\left(Q_{e}\right)$ of Ca-HA particles was reported to be in the typical range of $300-600 \mathrm{mg} \mathrm{g}^{-1}$, which is much larger than capacities observed with activated carbon as conventional sorbent [12]. In contact with metallic cations in aqueous solution, in particular with multivalent cations $\left(\mathrm{M}^{2+}, \mathrm{M}^{3+}\right)$, Ca-HA can incorporate these cations in its apatitic structure and release non-toxic $\mathrm{Ca}^{2+}$ to the liquid phase by an ion exchange reaction. Furthermore, heterogeneous nucleation of metal phosphates can form and metal phosphates grow on Ca-HA surfaces. The hydrated and protonated surfaces of Ca-HA in aqueous media have been described at length [13].

Usually, calcium phosphate based "sorbents" are mostly used under dried powder form for the removal of toxic metals from aqueous effluents, mainly due to the ease of handling solid particles. However, our last study on lead(II) removal showed that apatitic calcium phosphate in as-synthesized gel form prior to filtration was more active than that in dried powder form [12].

In this paper, we report a comparative study of the reactivity of different apatitic calcium phosphates, in both gel and powder form, obtained under different synthesis conditions, for the fixation of lead(II) as model toxic metal in an aqueous solution. Ca-HA is not a sorbent in the usual sense in that after contacting lead ions, the solid phase contains the initial calcium phosphate plus $\mathrm{Pb}^{2+}$ and minus $\mathrm{Ca}^{2+}$. So, there occurs a reaction best described as ion exchange, different from adsorption-desorption phenomena in which the solid substrate (sorbent) remains intact. We will demonstrate that the reaction is not limited to surface phenomena, but continues as the surface-formed lead phosphate spalls of the sorbent by erosion to create new reactive sites. The influence of aging of the calcium phosphate particles in water, their drying temperature, and the effect of remaining $\mathrm{CaCO}_{3}$ contents on the reactivity of Ca-HA is communicated.

\section{Materials and methods}

All chemical products used in this study had pure analytical grades, including $\mathrm{CaCO}_{3}, \mathrm{H}_{3} \mathrm{PO}_{4}$ and $\mathrm{Pb}\left(\mathrm{NO}_{3}\right)_{2}$. Apatitic calcium phosphates were synthesized using $\mathrm{CaCO}_{3}$ and $\mathrm{H}_{3} \mathrm{PO}_{4}$ as available starting materials. Details of the synthesis process were described elsewhere [14]. Briefly, $\mathrm{H}_{3} \mathrm{PO}_{4}$ was added in an aqueous suspension of $\mathrm{CaCO}_{3}$ particles, with theoretical $\mathrm{Ca} / \mathrm{P}$ molar ratio of 1.67 . The mixture was kept at $25-80^{\circ} \mathrm{C}$ under stirring for $48 \mathrm{~h}$. A stable gel was formed, which was composed of fine calcium phosphate particles and various amounts of unreacted calcium carbonate as a function of synthesis and drying temperatures (Table 1). Only traces of soluble calcium and phosphate species were present in the gel, as shown in our previous work [12]. Solid powders could be obtained by filtration of the gel on a $0.45 \mu \mathrm{m}$ filter paper followed by a drying stage at 25 or $105^{\circ} \mathrm{C}$. All gel or powder products were stored at room temperature in closed glass flasks. Table 1 lists all products investigated, obtained under different specified synthesis conditions.

Lead(II) sorption experiments were described elsewhere [12]. Briefly, lead nitrate was dissolved in permuted water to prepare an aqueous solution containing $6000 \mathrm{mg} \mathrm{L}^{-1}$ of $\mathrm{Pb}^{2+}$ (or 28.96 $\mathrm{mmol} \mathrm{L}-1$ of $\mathrm{Pb}^{2+}$ ). For each sorption experiment, $300 \mathrm{~mL}$ of this solution was introduced in a $700 \mathrm{~mL}$ stirred glass reactor at ambient temperature, ca. $25^{\circ} \mathrm{C}$. Then $2.4 \mathrm{~g}$ of the sorbent powder or an equivalent quantity of the fresh gel containing also $2.4 \mathrm{~g}$ of dried matter was rapidly added to the reactor under stirring (350 rpm). During the experiment, small aliquots were withdrawn from the reactor and filtered on $0.45 \mu \mathrm{m}$ filter paper. The liquid fraction was analyzed by inductive coupled plasma atomic emission spectroscopy (ICP-AES, HORIBA Jobin Yvon Ultima 2) for the determination of the concentration of soluble calcium, phosphorus, and lead. Fresh sorbents, conserved in sealed bottle at room conditions for less than 10 days were used. For the study on the influence of the conservation time, lead(II) sorption was carried out with both fresh and aged sorbent, this last one being kept for 9 months at room conditions.

Solid powders were characterized by different physico-chemical techniques. X-ray diffraction (XRD) data were collected using a Phillips Panalytical X'pert Pro MPD diffractometer with a $\mathrm{Cu} \mathrm{K \alpha}$ radiation source. Thermogravimetric analysis (TG) was carried out with a SDTQ600 analyzer (TA Instruments). Infra-red spectra (DRIFT) of solid samples were directly recorded on a Shimadzu FTIR 8400S spectrometer. Scanning electron microscopy (SEM) was measured on a Philips XL30 ESEM apparatus (FEI Company).

\section{Results and discussions}

\subsection{Influence of the synthesis temperature on the reactivity of sorbents}

The reactivity of the fresh gels synthesized at different temperatures (G25, G60 and G80, Table 1) for the removal of lead(II) is illustrated in Fig. 1. Unexpectedly, G25 containing the highest brushite and remaining $\mathrm{CaCO}_{3}$ contents was found to be the most active material, translated by its fastest lead(II) fixation kinetics.

Table 1

Synthesis conditions of apatitic calcium phosphates from $\mathrm{CaCO}_{3}$ and $\mathrm{H}_{3} \mathrm{PO}_{4}$ as initial reactants; other conditions: stirring rate of 400 rpm; reaction time of 48 h; the contents of remaining $\mathrm{CaCO}_{3}$ and brushite were obtained by TG analysis; n.a means not analyzed; ( ${ }^{*}$ ) powder sample obtained after aging $\mathrm{G} 25$ for 9 months, filtering and drying at room temperature.

\begin{tabular}{|c|c|c|c|c|c|}
\hline Synthesis $T,{ }^{\circ} \mathrm{C}$ & Filtration $(0.45 \mu \mathrm{m})$ & Drying $T,{ }^{\circ} \mathrm{C}$ & Remaining $\mathrm{CaCO}_{3}$ content, wt.\% & Brushite content, wt.\% & Labeled product \\
\hline \multirow[t]{4}{*}{25} & No & No & n.a & n.a & G25 \\
\hline & Yes & 25 & 23 & 55 & P25_DRY25 \\
\hline & Yes & 105 & 13 & 7 & P25_DRY105 \\
\hline & Yes & 25 & 15 & 26 & AGED_G25 (*) \\
\hline \multirow[t]{3}{*}{60} & No & No & n.a & n.a & G60 \\
\hline & Yes & 25 & 6 & 3 & P60_DRY25 \\
\hline & Yes & 105 & 6 & 3 & P60_DRY105 \\
\hline \multirow[t]{3}{*}{80} & No & No & ND & ND & G80 \\
\hline & Yes & 25 & 1 & 1 & P80_DRY25 \\
\hline & Yes & 105 & 1 & 1 & P80_DRY105 \\
\hline
\end{tabular}



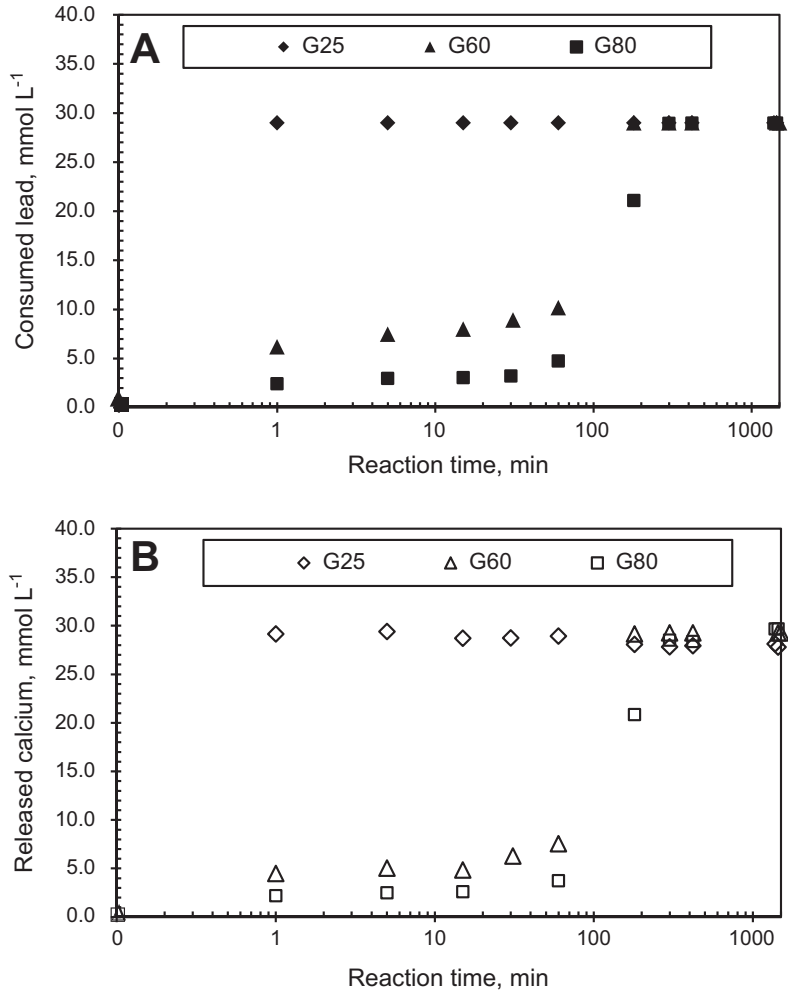

Fig. 1. Consumed lead (a) and released calcium (b) during the sorption experiments using different gels obtained at different synthesis temperatures.

Lead(II) was completely removed within the first minute of reaction by G25 (Fig. 1(a)). When the temperature of Ca-HA synthesis increased to 60 and $80^{\circ} \mathrm{C}$, the yield in $\mathrm{Ca}-\mathrm{HA}$ increased and the unconverted $\mathrm{CaCO}_{3}$ contents of G60 and G80 decreased. However, the removal of lead(II) was only complete between 120 and $180 \mathrm{~min}$ of contact, using these two sorbents. In parallel with the removal of lead(II), calcium(II) was released to the solution and its concentration is shown in Fig. 1(b). The molar concentration of released calcium during lead(II) fixation was close to that of removed lead(II), as observed previously for apatitic calcium phosphate sorbents $[12,15]$.

\subsection{Influence of the drying step}

Standard drying is generally carried out at $105^{\circ} \mathrm{C}$ under air atmosphere. However, this temperature may have significant effects on the evolution of physico-chemical properties and reactivity of the solid calcium phosphates since all sorbents were synthesized at temperatures below $105^{\circ} \mathrm{C}$. Thus, the solid fractions obtained from the filtration of G25 and G80 were dried at 25 and $105^{\circ} \mathrm{C}$, and were thereafter tested in the removal of lead(II). Fig. 2 compares the reactivity of G25 and G80 with the corresponding dried solid products.

In all cases, the trend is similar for the products synthesized at 25 (Fig. 2(a)) and $80^{\circ} \mathrm{C}$ (Fig. 2(b)). Sorbents dried at $25^{\circ} \mathrm{C}$ (P25_DRY25 and P80_DRY25) had similar reactivity for lead(II) removal compared to the corresponding gels (G25 and G80), indicating that the filtration and drying step at $25^{\circ} \mathrm{C}$ did not change physico-chemical properties of calcium phosphate particles present in the gels. On the other hand, sorbents dried at $105^{\circ} \mathrm{C}$ (P25_DRY105 and P80_DRY105) had slower lead(II) sorption kinetics, compared to the corresponding gels and powder sorbents dried at $25{ }^{\circ} \mathrm{C}$. Previous work described the specificities of the surface of solid apatitic calcium phosphate, consisting of hydrated layers
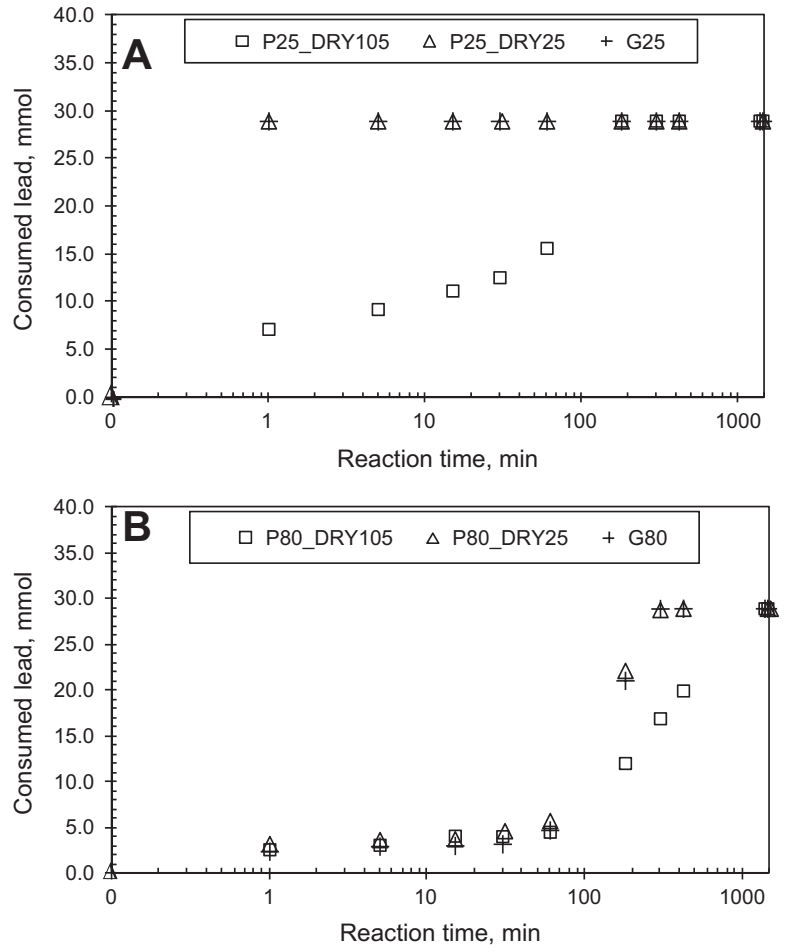

Fig. 2. Consumed lead during the sorption experiment using: (a) sorbents synthesized at $25^{\circ} \mathrm{C}$; and (b) sorbents synthesized at $80^{\circ} \mathrm{C}$; powder sorbents were either dried at $25^{\circ} \mathrm{C}$ or $105^{\circ} \mathrm{C}$.

which have higher ionic exchange capacity than the apatite core $[13,16,17]$. The drying at $105^{\circ} \mathrm{C}$ may remove or modify the hydrated layers compared to those of fresh gel or powder dried at room temperature, and therefore reduces the lability of the species on the surface of apatitic particles. Hydrogenophosphate groups are present on the surfaces of $\mathrm{Ca}-\mathrm{HA}$ in water near neutral $\mathrm{pH}$ values. The unfavorable effect of the thermal treatment step on the reactivity of apatitic calcium phosphates in the removal of heavy metals was previously observed $[18,19]$.

\subsection{Determination of the sorption capacity and influence of the conservation time}

Further experiments were carried out with smaller amounts of G25 in order to determine the sorption capacity of this material, which had the best reactivity among the synthesized products. The objective was to determine the shelf life of the gel, and analyze any decrease in sorption performance as a function of aging time (conservation). Fig. 3 shows the evolution of the concentration of consumed lead(II) during the experiment, when a quantity of fresh G25 equivalent to $0.75 \mathrm{~g}$ powder sorbent was used. Under similar conditions, another experiment was carried out using G25 aged for 9 months in a hermetic flask at room temperature in order to investigate the effect of conservation time (aging) on the reactivity of this sorbent.

As expected for the fresh G25, lead(II) removal took place rapidly within the first minute of contact with fresh gel. The removal of lead(II) reached equilibrium after about $6 \mathrm{~h}$ of contact and the concentration of removed lead(II) leveled at $14.8 \mathrm{mmol} \mathrm{L}^{-1}$. From this result, the sorption capacity $\left(Q_{e}\right)$ of fresh $G 25$ could be derived, and was found to represent $1226 \mathrm{mg}$ of removed $\mathrm{Pb}^{2+}$ per gram of equivalent powder sorbent.

The conservation of G25 for 9 months at room temperature in a hermetic flask decreased dramatically its reactivity. The removal of 


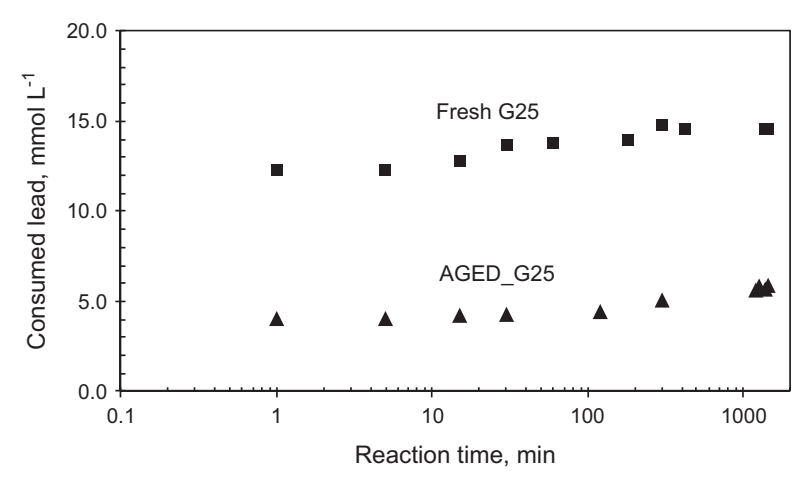

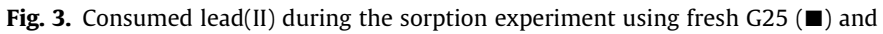
AGED_G25 ( $\Lambda$ ); Sorption conditions: ca. $25^{\circ} \mathrm{C}$; $350 \mathrm{rpm}$; $300 \mathrm{~mL}$ of $28.96 \mathrm{mmol} \mathrm{L}$ of lead(II); mass of gel used equivalent to $0.75 \mathrm{~g}$ of powder dried at $105^{\circ} \mathrm{C}$.

lead(II) seemed to be at equilibrium after $24 \mathrm{~h}$ of contact with AGED_G25 sorbent. From the concentration of removed lead(II) of $5.8 \mathrm{mmol} \mathrm{L}^{-1}, Q_{e}$ of AGED_G25 was calculated at $480 \mathrm{mg}$ of removed $\mathrm{Pb}^{2+}$ per gram of equivalent powder sorbent.

In all cases, the initial $\mathrm{pH}$ of lead(II) nitrate solution was 5.2. After $24 \mathrm{~h}$ of contact with calcium phosphate-based sorbent, the final $\mathrm{pH}$ of the reaction mixture was equilibrated at $6.2-7.5$ as a function of sorbent used. XRD characterization in the next section reveals that only trace amounts of lead oxides were formed in these conditions. Some results on the evolution of $\mathrm{pH}$ during lea$\mathrm{d}(\mathrm{II})$ removal experiment was previously reported in our earlier work [20].

In order to better understand the influence of different parameters on the reactivity of apatitic calcium phosphate sorbents, various physico-chemical characterizations were carried out for the powder sorbents before and after use, and the results are discussed in the next sections.

\subsection{XRD characterization}

Crystalline phases of powder materials were determined by XRD technique. Fig. 4 shows the XRD patterns of the powders synthesized at $25-80^{\circ} \mathrm{C}$, and dried at $25-105^{\circ} \mathrm{C}$ before lead(II) removal. For P25_DRY25 (synthesized and dried at $25^{\circ} \mathrm{C}$ ), residual $\mathrm{CaCO}_{3}$ (JCPDS standard No. 01-081-2027) and brushite (JCPDS standard No. 00-011-2093) were found as the two main crystalline phases. The only apatitic compound found in this powder was octacalcium phosphate (OCP, JCPDS standard No. 00-026-1056), existing at smaller content compared to those of residual $\mathrm{CaCO}_{3}$ or brushite. For P25_DRY105, obtained when the drying was carried out at $105^{\circ} \mathrm{C}$, Ca-HA appeared as new crystalline phase. This phase seemed to be the result of the solid-solid reaction between brushite, OCP and residual $\mathrm{CaCO}_{3}$ at $105^{\circ} \mathrm{C}$ because the relative intensity of these phases decreased compared to the product dried at $25^{\circ} \mathrm{C}$. So the drying at $105^{\circ} \mathrm{C}$ not only removed free water, but also favored the formation of $\mathrm{Ca}-\mathrm{HA}$, which is thermodynamically the most stable calcium phosphate.

For P80_25 and P80_105, as previously communicated [14], the synthesis temperature of $80^{\circ} \mathrm{C}$ allowed the complete dissolution of $\mathrm{CaCO}_{3}$ and promoted the formation of $\mathrm{Ca}-\mathrm{HA}$ as the main crystalline phase. No significant effect of the drying temperature in the range of $25-105^{\circ} \mathrm{C}$ was observed for these powders, and judging from the broad line widths of the diffraction lines, the solids were nanocrystalline or partly amorphous.

Fig. 5 presents XRD patterns of different solids after lead(II) removal, using dried powder or gel sorbents. They had similar XRD patterns to each other and in all cases, lead hydroxyapatite (JCPDS standard No. 01-087-2478) was found as the main crystalline

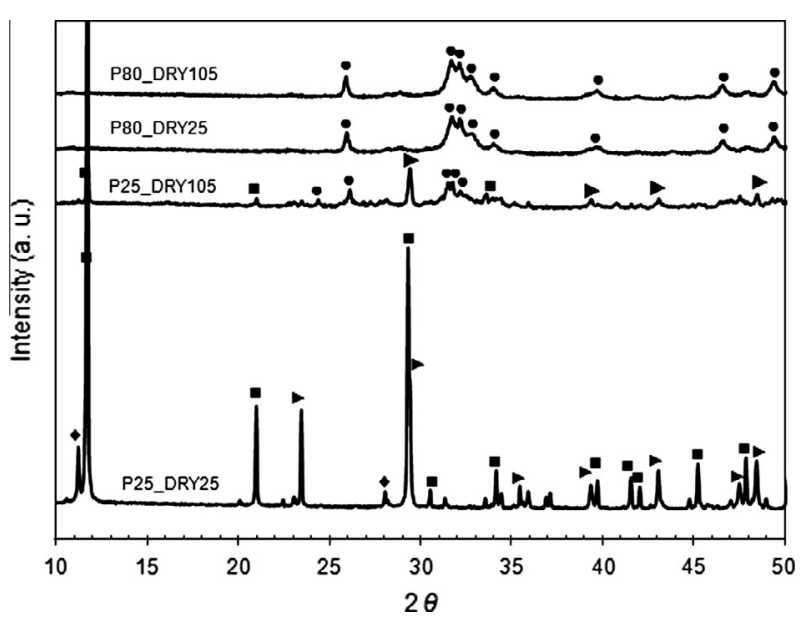

Fig. 4. XRD patterns of the powders synthesized at $25-80^{\circ} \mathrm{C}$, and dried at $25-105^{\circ} \mathrm{C}$ before lead(II) removal; calcite $(\bullet)$; brushite $(\mathbf{\square})$; octacalcium phosphate (४) Ca-HA (•)

phase. Lead oxides (JCPDS standard Nos. 01-078-1664 or 01-072-1551) seemed to be present but only at trace amounts. In addition to these phases, residual $\mathrm{CaCO}_{3}$ present at low contents was also revealed for the sorbents synthesized at $25{ }^{\circ} \mathrm{C}$ and trace amounts of poorly-crystalline Ca-HA were detected.

\subsection{TG analysis}

Fig. 6 presents TG curves of solid powders before and after lea$\mathrm{d}(\mathrm{II})$ removal. All solids had the first weight loss around $100^{\circ} \mathrm{C}$, which is attributed to the removal of surface moisture. For both solids synthesized at $80^{\circ} \mathrm{C}$ and dried at 25 or $105^{\circ} \mathrm{C}$ (P80_DRY25 and P80_DRY105), slight and continuous weight losses were observed up to about $650^{\circ} \mathrm{C}$, due to the dehydration of lattice molecular water $[14,20]$. No significant weight loss near $610^{\circ} \mathrm{C}$ was observed, which confirms again that the synthesis temperature of $80{ }^{\circ} \mathrm{C}$ was sufficient for total decomposition of $\mathrm{CaCO}_{3}$ during the Ca-HA synthesis. Above $650{ }^{\circ} \mathrm{C}$, a small weight loss was observed, explained previously by the decarbonation of carbonated apatite (CAP) [14]. The presence of CAP was highlighted by FTIR analysis (Supporting information 1 and 2).

On the other hand, the drying had remarkable effect on the solids synthesized at $25^{\circ} \mathrm{C}$. Mono-calcium phosphate monohydrate (MCPM, $\mathrm{Ca}\left(\mathrm{H}_{2} \mathrm{PO}_{4}\right) 2 \cdot \mathrm{H}_{2} \mathrm{O}$ ), which has a typical dehydration around

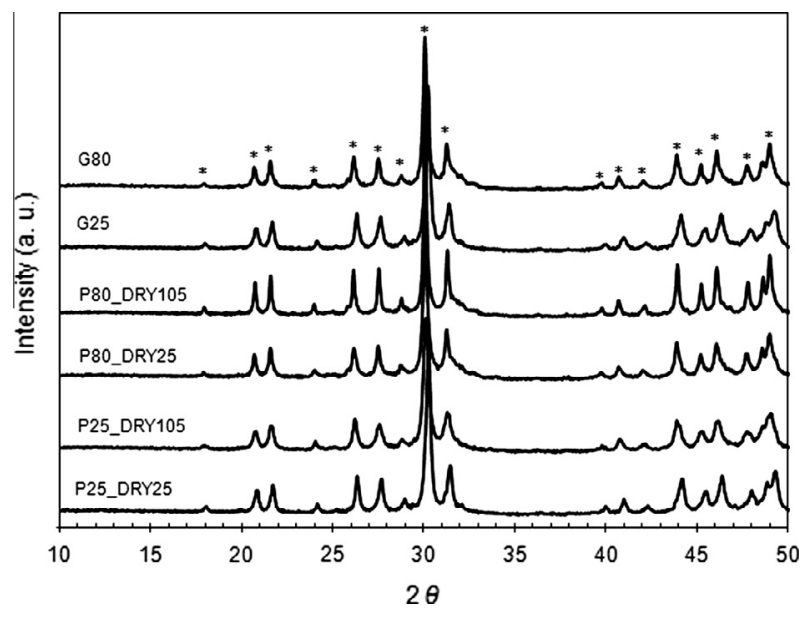

Fig. 5. XRD patterns of the sorbents recovered after contact with lead(II) solution; lead hydroxyapatite $\left({ }^{*}\right)$. 

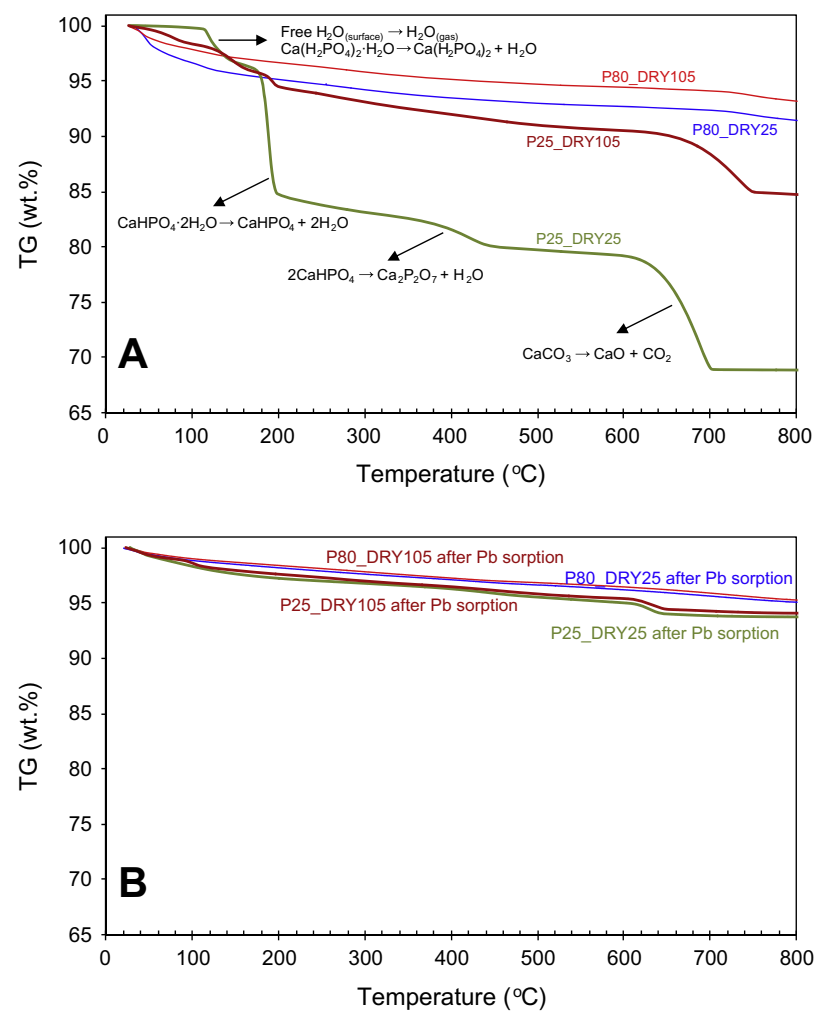

Fig. 6. TG analysis of the powder sorbents before (A) and after (B) lead(II) sorption.

$110^{\circ} \mathrm{C}$, was present in both solids dried at room temperature (P25_DRY25) and at $105^{\circ} \mathrm{C}$ (P25_DRY105) [21]. The dehydration of brushite $\left(\mathrm{CaHPO}_{4} \cdot 2 \mathrm{H}_{2} \mathrm{O}\right)$ takes place around $180{ }^{\circ} \mathrm{C}$ [21]. From TG curves, its content could be calculated which was found at 55 and $7 \mathrm{wt} . \%$ for the product dried at $25^{\circ} \mathrm{C}$ (P25_DRY25) and at $105^{\circ} \mathrm{C}$ (P25_DRY105), respectively (Table 1). A similar phenomenon was observed for monetite $\left(\mathrm{CaHPO}_{4}\right)$ and remaining calcite. Their contents were higher in P25_DRY25 than in P25_DRY105. So the drying at $105{ }^{\circ} \mathrm{C}$ pushed the reaction of remaining calcite with different acid calcium phosphates such as MCPM, brushite, and monetite to the formation of Ca-HA as the more stable calcium phosphate phase, as found previously by XRD results in Fig. 4.

From the results of lead(II) removal in Figs. 1-3, and the composition of the sorbents used for lead(II) removal (Table 1), we observe that the higher the contents of brushite, monetite and MCPM, the better was the reactivity of the sorbents. In the other word, brushite, monetite and MCPM were more active than $\mathrm{Ca}-\mathrm{HA}$. The reaction of solid calcium phosphate particles with free lead(II) ions in solution to form solid lead hydroxyapatite layers (hydroxypyromorphite) on the external surface of calcium phosphate particles and release free calcium(II) must be considered as a biphasic liquid-solid reaction. This reaction is favorable when acidic orthophosphate species are more available in the reaction medium. Thus, brushite, monetite and MCPM with higher solubility compared to $\mathrm{Ca}-\mathrm{HA}[22]$ and solids with $\mathrm{HPO}_{4}^{2-}$ surface groups are more active than dehydrated Ca-HA for the fixation of lead(II). So, the increase of the temperature for synthesis and/or drying of the sorbents was favorable for the conversion of brushite, monetite and MCPM to apatitic phases, and so decreased the reactivity of the sorbents. The similar phenomenon was observed when the conservation time of the sorbents increased. Table 1 shows that, a half of brushite in the fresh G25 was evolved into apatitic phase during 9 months of conservation at room conditions, which decreased dramatically its reactivity for lead(II) removal (Fig. 3). FTIR and SEM analyses of the fresh and aged sorbent confirmed the evolution of brushite into apatitic products (Supporting information 3 and 4).

TG curves of the solids recovered after contact with lead(II) solution are presented in Fig. 6(B). For the sorbents synthesized at $80^{\circ} \mathrm{C}$, a continuous weight loss within the studied temperature range was observed, due to the removal of surface moisture and to the dehydration of lattice molecular water. The sorbents synthesized at $25^{\circ} \mathrm{C}$ had very similar TG curves, except for small decarbonations of remaining calcite around $610^{\circ} \mathrm{C}$. On the other hand, other calcium phosphates including MCPM, brushite and monetite were no longer present. According to the XRD results in Fig. 5, these calcium phosphates were converted to lead(II) hydroxyapatite, as shown previously $[12,20]$.

\subsection{SEM characterization}

SEM study was carried out in order to investigate the change due to the drying step and the fixation of lead(II) on calcium phosphate particles. Fig. 7 shows the surface morphology of the powders, synthesized at $25^{\circ} \mathrm{C}$. For P25_DRY25, particles of platelet structure were dominant, which can be explained by the abundance of brushite in this powder, as shown previously by TG analysis (Fig. 6) [21]. When the drying temperature rose to $105^{\circ} \mathrm{C}$, the particles of platelet structure disappeared corresponding to its transformation to apatitic phase. In both cases, particle sizes varied in a large range, from less than $1 \mu \mathrm{m}$ up to hundreds of $\mu \mathrm{m}$, resulting from agglomeration phenomena.

Fig. 8 presents SEM images of the external surface of particles recovered after the contact of P25_DRY25 (Fig. 10A, B, and C) and P25_DRY105 (Fig. 8D, E, and F) with lead(II) solution. The results were similar to each other, with the disappearance of particles of platelet structure. In parallel, a large number of particles smaller than about $1 \mu \mathrm{m}$ appeared, in particular for the sample recovered from the removal of lead(II) by P25_DRY25 (Fig. 8A). At higher magnifications, particles of needle-like morphology were dominant. This morphology resulted from the fixation of lead(II) on the surface of calcium phosphate particles, was confirmed by EDX analysis (results not shown), and corresponds to the formation of hydroxypyromorphite [23].

The bi-phasic reaction between lead(II) ions in solution and solid calcium phosphate particles is a surface phenomenon, with the fixation of lead(II) on the surface of phosphate crystals. To highlight this, a SEM study of polished samples of resin embedded particles recovered after lead(II) sorption was performed in order to analyze qualitatively the composition inside particles. The samples were polished gently to ensure a plane surface where particles were cut without damaging their morphology.

As observed in Fig. 9, lead(II) was only immobilized on the surface of particles, for both small (Fig. 9A) and large (Fig. 9B) particles. In some case, the fixation of lead(II) on the surface of open-pores of particles can be observed (arrow, Fig. 9A). In fact, in contact with lead(II) solution, Ca-HA particles were quickly covered by layers of lead hydroxyapatite $\left(\mathrm{Pb}_{10}\left(\mathrm{PO}_{4}\right)_{6}(\mathrm{OH})_{2}\right.$, hydroxypyromorphite), as identified by XRD characterization. This inhibited further immediate contact of free lead(II) in solution with the inside of the calcium phosphate matrix, except in open pores, and caused the fixation of lead(II) to slow down. We relate the slower second lead uptake phase to the reaction occurring following lead phosphate spalling and regeneration of fresh calcium phosphate surfaces. Similar results were observed for other sorbents recovered after contact with lead(II) solution. Previous investigators described the initial rapid heavy metal uptake followed by a slower subsequent uptake [15].

For the solids synthesized at $80^{\circ} \mathrm{C}$, before lead(II) removal, there was no significant difference on the external morphology of particles for the products dried at room temperature and $105^{\circ} \mathrm{C}$ 

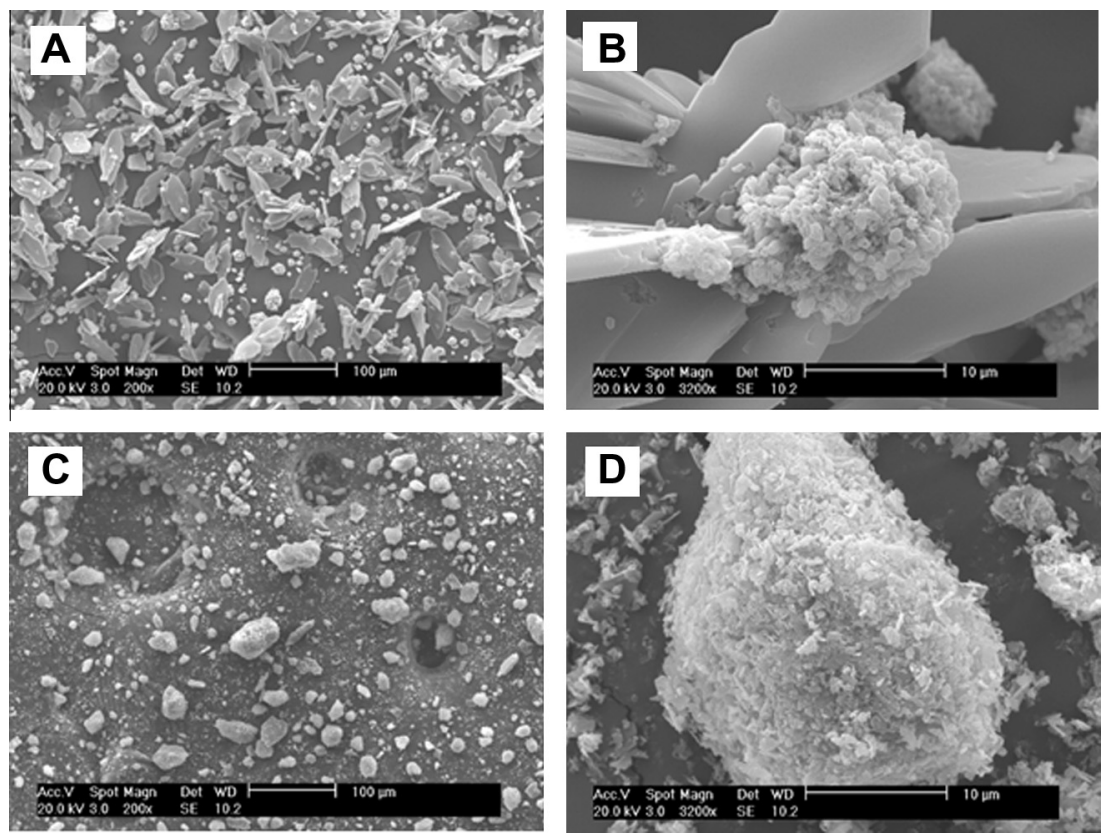

Fig. 7. SEM images of P25_DRY25 (A and B), and P25_DRY105 (C and D). Images obtained with a detector for secondary electrons (SE).
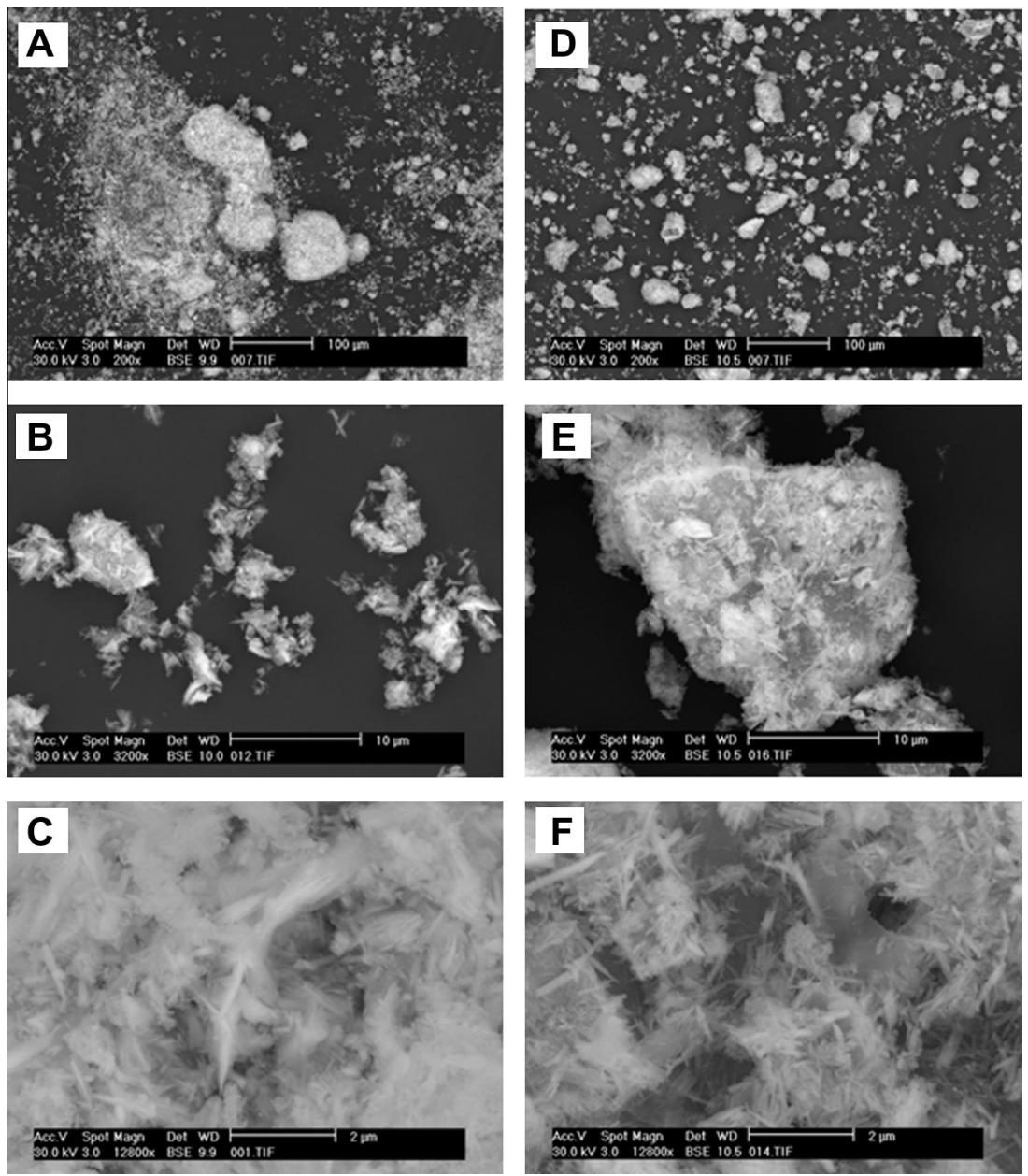

Fig. 8. SEM images of the solids recovered after lead(II) sorption: P25_DRY25 (A, B, and C); and P25_DRY105 (D, E, and F). Images obtained with a detector for back-scattered electrons (BSE). 

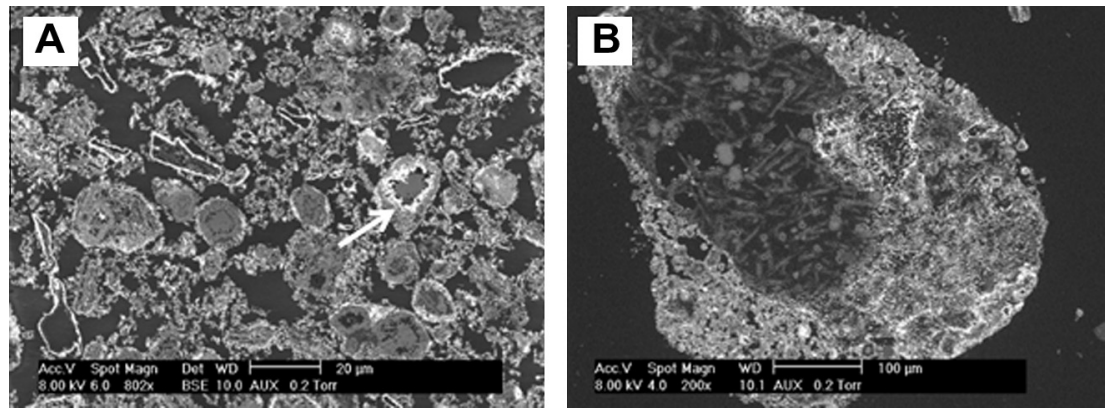

Fig. 9. SEM images of cut and polished particles recovered after contact of P25_DRY25 with lead(II) solution; lead(II) has the highest contrast compared to calcium, phosphorus and oxygen. Images obtained with a detector for back-scattered electrons (BSE).
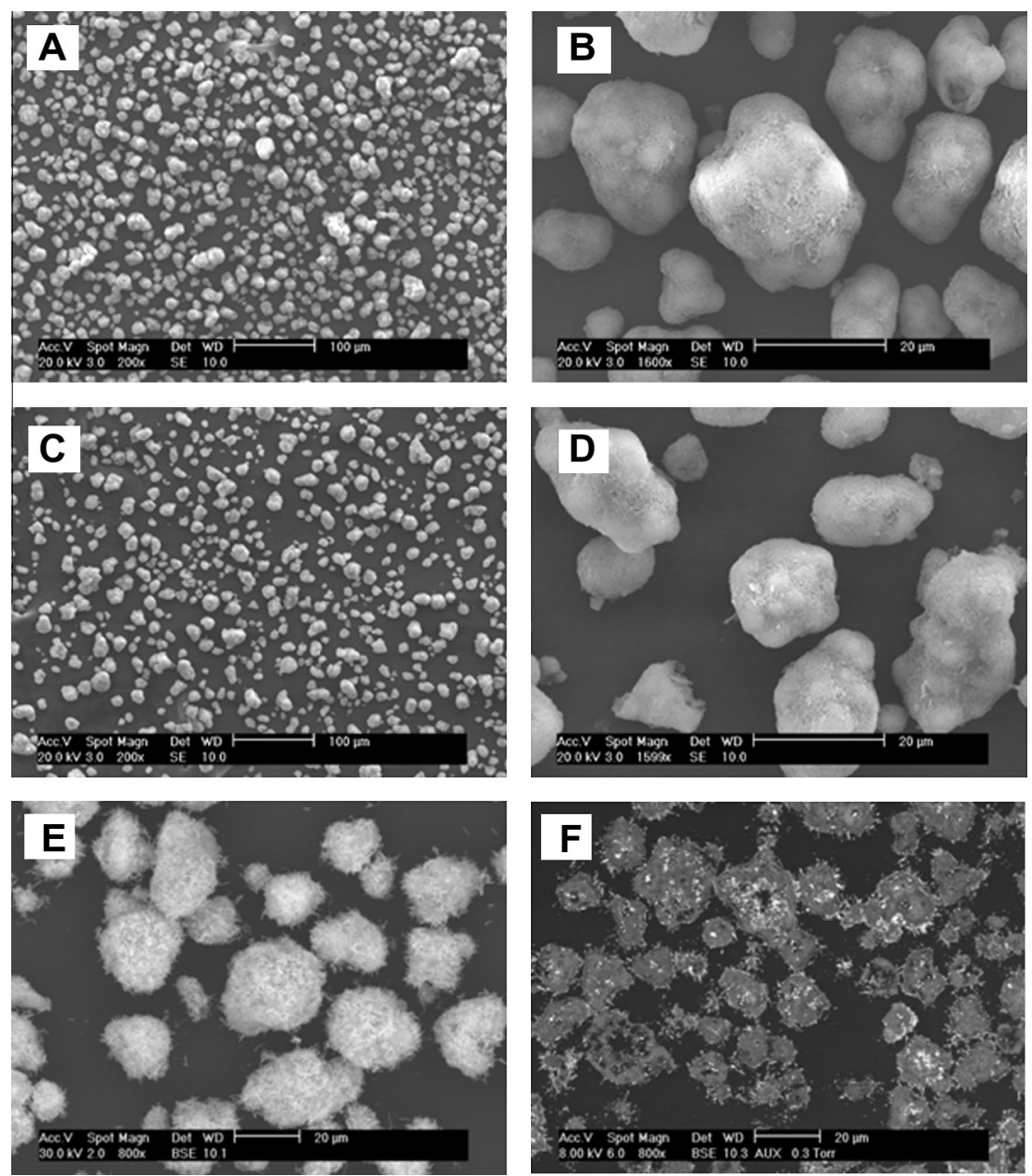

Fig. 10. SEM images of P80_DRY25 (A and B), and P80_DRY105 (C and D) before lead(II) removal; Observation of external surface (E) and look inside cut and polished particles (F) of P80_DRY105 after contact with lead(II) solution; Lead(II) has the highest contrast compared to calcium, phosphorus and oxygen; (A, B, C, and D) images obtained with a detector for secondary electrons (SE); (E and F) images obtained with a detector for back-scattered electrons (BSE).

(Fig. 10A, B, C, and D). In both cases, regular spherical particles were formed, resulting also from the agglomeration of smaller particles. After contact with lead(II) solution, as mentioned above, the look inside cut and polished particles recovered highlighted the fixation of lead(II) on the surface of particles (Fig. 10E and F).

\subsection{Pilot scale}

Much research has focused on Ca-HA based materials for the removal of heavy metals from synthetic, laboratory-made aqueous effluents [15,24-26]. Results obtained are usually very satisfactory with good performance reported for the retention of different heavy metals by Ca-HA. However, to the best of our knowledge, no process development for the application of $\mathrm{Ca}-\mathrm{HA}$ based materials in the treatment of wastewaters has been described at industrial scale. The reason is certainly due to the high cost of Ca-HA materials made by conventional methods. For environmental application, the minimization of global cost is crucial, as is the absence of byproducts such as ammonium nitrate during Ca-HA synthesis. So, Ca-HA has to be synthesized by the simplest method and from 


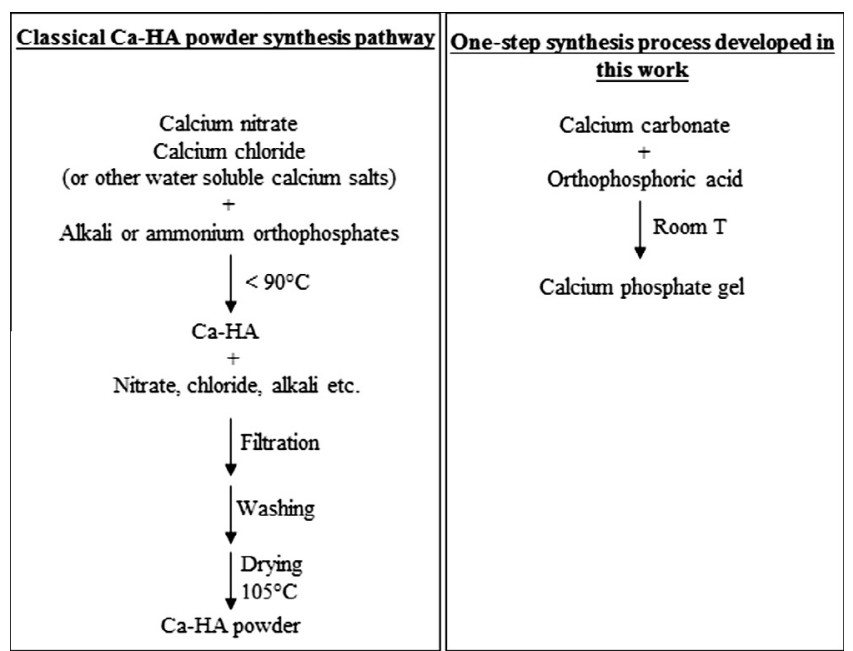

Scheme 1. Comparison of the one-step synthesis process developed in this work with the conventional Ca-HA powder synthesis process.

the cheapest starting materials. Scheme 1 compares our synthesis process and the most popular synthesis way used in the literature from water soluble calcium salts.

It is obvious that calcium carbonate and orthophosphoric acid are the cheapest calcium and orthophosphate sources, as starting materials for the synthesis of calcium phosphates. Since carbon dioxide is the only co-product of the reaction between calcium carbonate and orthophosphoric, which automatically leaves the mixture during the reaction, no purification (filtration, washing, drying) is required for the gel product formed. On the other hand, conventional Ca-HA powder is obtained by multi-step synthesis process which generates also a great quantity of wastewater containing all counter-ions such as nitrate, chloride, alkali, and ammonium. Finally, the results obtained in this work showed that fresh calcium orthophosphate gel had much higher reactivity compared to conventional Ca-HA powder.

From the results obtained on the synthesis of calcium orthophosphate gel and its performance in the removal of lead(II), we were also successful in the development of a pilot, being operated with several tons of calcium phosphate gel, for the treatment of real wastewater contaminated by heavy metals (Scheme 2). More details on the composition of the wastewater used for pilot test can be found elsewhere [27]. The results were also very satisfactory for the treatment of a mixture of domestic and industrial wastewaters containing both heavy metals and organic pollutants. Calcium orthophosphate gel was found to be efficient for the retention of both heavy metals and organic compounds. Benchmarking showed that the wastewater treatment based on the large-scale use of calcium orthophosphate gel can be exploited at industrial

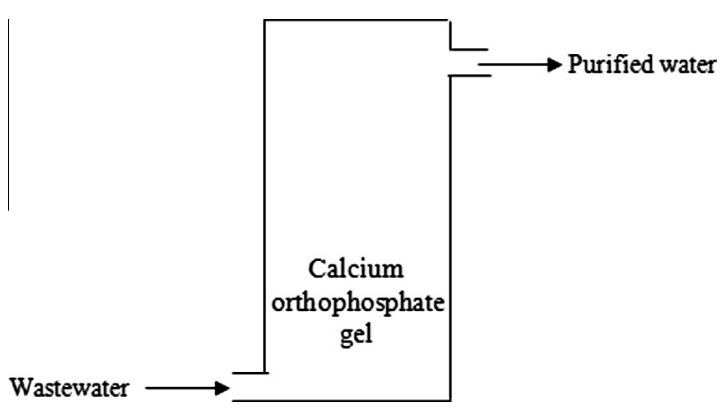

Scheme 2. Simplified sketch of the pilot using calcium orthophosphate gel for the treatment of wastewaters contaminated by both heavy metals and organic pollutants. scale. This will be communicated in more details in a forthcoming paper.

\section{Conclusions}

Calcium phosphate based materials with various compositions could be obtained from calcium carbonate powder and orthophosphoric acid by the one-step synthesis process at moderate conditions. All calcium phosphates present in the solids formed participated to the immobilization of lead(II) in an aqueous solution. Among them, the intermediates of the synthesis process, including brushite, monetite and MCPM were more active than the final more stable Ca-HA phase. The highest sorption capacity was obtained with G25 and P25_DRY25, which were synthesized at $25{ }^{\circ} \mathrm{C}$ and contained up to $55 \mathrm{wt} . \%$ of brushite.

Future work will focus on the use of other particulate calcium phosphates having higher water solubility, such as MCPM, brushite or monetite; and the functionalization of more inert solid supports by surface modifications with labile orthophosphate species.

\section{Acknowledgement}

The authors gratefully acknowledge colleagues at RAPSODEE center, Christine Roland and Nathalie Lyczko, for technical help.

\section{Appendix A. Supplementary material}

Supplementary data associated with this article can be found, in the online version, at http://dx.doi.org/10.1016/j.cej.2014.01.032.

\section{References}

[1] S. Telisman, B. Colak, A. Pizent, J. Jurasovic, P. Cvitkovic, Reproductive toxicity of low-level lead exposure in men, Environ. Res. 105 (2007) 256-266.

[2] X.G. Chen, R.D. Poretz, Lead causes human fibroblasts to mis-sort arylsulfatase A, Toxicology 163 (2001) 107-114.

[3] R. Wagner, Large lead/acid batteries for frequency regulation, load levelling and solar power applications, J. Power Sources 67 (1997) 163-172.

[4] P. Lailler, J.-F. Sarrau, C. Sarrazin, Comparative study for "36 V" vehicle applications: advantages of lead-acid batteries, J. Power Sources 95 (2001) 5867.

[5] J. Garche, A. Jossen, H. Dijring, The influence of different operating conditions, especially over-discharge, on the lifetime and performance of lead/acid batteries for photovoltaic systems, J. Power Sources 67 (1997) 201-212.

[6] K. Yao, L. Zhang, X. Yao, W. Zhu, Growth, structure, and morphology of lead titanate crystallites in the sol-gel derived glass-ceramics, Mater. Sci. Eng. B41 (1996) 322-328.

[7] A. Turner, Y.S.K. Sogo, Concentrations and bioaccessibilities of metals in exterior urban paints, Chemosphere 86 (2012) 614-618.

[8] T. Suzuki, K. Ishigaki, M. Miyake, Synthetic hydroxyapatites as inorganic cation exchangers. Part 3. Exchange characteristics of lead ions $\left(\mathrm{Pb}^{2+}\right)$, J. Chem. Soc. Faraday Trans. 1 (80) (1984) 3157-3165.

[9] M. Miyake, K. Watanabe, Y. Nagayama, H. Nagasawa, T. Suzuki, Synthetic carbonate apatites as inorganic cation exchangers, J. Chem. Soc., Faraday Trans. 86 (1990) 2303-2306.

[10] Q.Y. Ma, T.J. Logan, S.J. Traina, Effects of $\mathrm{NO}_{3}^{-}, \mathrm{Cl}^{-}, \mathrm{F}^{-}, \mathrm{SO}_{4}^{2-}$, and $\mathrm{CO}_{3}^{2-}$ on $\mathrm{Pb}^{2+}$ immobilization by hydroxyapatite, Environ. Sci. Technol. 28 (1994) 408-418.

[11] A. Nzihou, P. Sharrock, Role of phosphate in the remediation and reuse of heavy metal polluted wastes and sites, Waste Biomass Valoriz. 1 (2010) 163174.

[12] D. Pham Minh, H. Sebei, A. Nzihou, P. Sharrock, Apatitic calcium phosphates: synthesis, characterization and reactivity in the removal of lead(II) from aqueous solution, Chem. Eng. J. 198-199 (2012) 180-190.

[13] C. Rey, C. Combes, C. Drouet, H. Sfihi, A. Barroug, Physico-chemical properties of nanocrystalline apatites: Implications for biominerals and biomaterials, Mater. Sci. Eng., C 27 (2007) 198-205.

[14] D. Pham Minh, N.D. Tran, A. Nzihou, P. Sharrock, One-step synthesis of calcium hydroxyapatite from calciumccarbonate and orthophosphoric acid under moderate conditions, Ind. Eng. Chem. Res. 52 (2013) 1439-1447.

[15] S. Baillez, A. Nzihou, D. Bernache-Assolant, E. Champion, P. Sharrock, Removal of aqueous lead ions by hydroxyapatites: Equilibria and kinetic processes, J. Hazard. Mater. A139 (2007) 443-446.

[16] S. Cazalbou, D. Eichert, C. Drouet, C. Combes, C. Rey, Minéralisations biologiques à base de phosphate de calcium, C. R. Palevol 3 (2004) 563-572.

[17] C. Rey, C. Combes, C. Drouet, M.J. Glimcher, Bone mineral: update on chemical composition and structure, Osteoporos. Int. 20 (2009) 1013-1021. 
[18] S. Sugiyama, T. Ichii, H. Matsumoto, H. Hayashi, Effect of calcinations and sieving of calcium hydroxyapatite on ion-exchangeability with lead cation in the presence and absence of $\mathrm{HCl}$, Adv. Environ. Res. 6 (2002) 285-289.

[19] M. Hadioui, P. Sharrock, M.O. Mecherri, V. Brumas, M. Fiallo, Reaction of lead ions with hydroxylapatite granules, Chem. Pap. 62 (2008) 516-521.

[20] D. Pham Minh, N.D. Tran, A. Nzihou, P. Sharrock, Hydroxyapatite gel for the improved removal of $\mathrm{Pb}^{2+}$ ions from aqueous solution, Chem. Eng. J. 232 (2013) 128-138.

[21] D. Pham Minh, N. Lyczko, H. Sebei, A. Nzihou, P. Sharrock, Sharrock, synthesis of calcium hydroxyapatite from calcium carbonate and different orthophosphate sources: a comparative study, Mater. Sci. Eng., B 177 (2012) 1080-1089.

[22] J.C. Elliott, Studies in Inorganic Chemistry 18: Structure and Chemistry of the Apatites and Other Calcium Orthophosphates, Elsevier, Amsterdam/London/ New York/Tokyo, 1994. pp. 9-34.
[23] E. Kamiishi, S. Utsunomiya, Nano-scale reaction processes at the interface between apatite and aqueous lead, Chem. Geol. 340 (2013) 121-130.

[24] Y. Hashimoto, T. Sato, Removal of aqueous lead by poorly-crystalline hydroxyapatites, Chemosphere 69 (2007) 1775-1782.

25] I. Smiciklas, S. Dimovic, I. Plecas, M. Mitric, Removal of $\mathrm{Co}^{2+}$ from aqueous solutions by hydroxyapatite, Water Res. 40 (2006) 2267-2274.

[26] I. Mobasherpour, E. Salahi, M. Pazouki, Comparative of the removal of $\mathrm{Pb}^{2+}$ $\mathrm{Cd}^{2+}$ and $\mathrm{Ni}^{2+}$ by nano crystallite hydroxyapatite from aqueous solutions: adsorption isotherm study, Arab. J. Chem. 5 (2012) 439-446.

[27] H. Sebei, N. Lyczko, D. Pham Minh, A. Nzihou, P. Sharrock, Valorisation of carbonate waste into hydroxyapatite for the remediation of heavy metals, in: WasteEng 12 (4th International Conference on Engineering for Waste and Biomass Valorisation), Porto, Portugal, ISBN 979-10-91526-00-5, vol. 2, 2012, pp. 578-585. 